\title{
Ecotourism and Its Impact on Local Community in Sauraha, Chitwan National Park, Nepal
}

Pratiksha Acharya ${ }^{1}$, Hom Bahadur Chhetri ${ }^{1}$, Sandhya Karki ${ }^{1}$, Puja Sharma ${ }^{2}$, Shankar Tripathi ${ }^{2}$, Saru Gahatraj ${ }^{1}$, Deepa Dahal $^{1}$, Deepak Gautam ${ }^{1 *}$

${ }^{1}$ Institute of Forestry, Tribhuvan University, Nepal

${ }^{2}$ Faculty of Forestry, Agriculture and Forestry University, Hetauda, Nepal

DOI: $\underline{10.36347 / \text { sjahss.2020.v08i07.003 }}$

| Received: 04.05.2020 | Accepted: 28.06.2020 | Published: 18.07.2020

*Corresponding author: Deepak Gautam

Abstract

Original Research Article

Ecotourism is getting popular in Nepal. This study was conducted in Sauraha, buffer zone area of Chitwan National Park (CNP) to access about the ecotourism and its impact. The main thrust of this study was to analyze the positive and negative economic, environmental and socio-cultural impacts of ecotourism on local community. Primary information was collected by using various tools of PRA including semi-structured questionnaire, focus group discussions and key informants interview. Index of Relative Ranking and Index of Perception Availability were used to analyze the people perception towards ecotourism. Almost all the respondents have positive response towards the economic and socio cultural impact of eco-tourism while some of them have pointed the negative environmental impact. Index of Relative Ranking was received maximum (0.93) for Jungle safari which indicates that most of the tourist visit Sauraha for Jungle safari in CNP. Generation of new employment opportunities, conservation of local culture and emergence of noise and visual pollution were found as impact of eco-tourism in Sauraha.

Keywords: Economic, Environmental, Socio-cultural, Employment opportunities.

Copyright @ 2020: This is an open-access article distributed under the terms of the Creative Commons Attribution license which permits unrestricted use, distribution, and reproduction in any medium for non-commercial use (NonCommercial, or CC-BY-NC) provided the original author and source are credited.

\section{INTRODUCTION}

Tourism industry is growing rapidly worldwide and is one of the world's largest industries, particularly in the Asia and Pacific region [1]. Among the varieties of the tourism, ecotourism protects and conserves numerous elements of nature along with providing employment opportunities to the people [2]. Ecotourism has been recognized as one of the sustainable green economy by United Nations Environmental Programme [3]. It prioritizes tourism industry with sustainable development goals of nature conservation, benefitting local people and educating tourists towards sustainability [4]. The International Ecotourism Society (TIES) defines ecotourism as "responsible travel to natural areas that conserves the environment, sustains the well-being of the local people, and involves interpretation and education" [5]. The fundamental function of the ecotourism is to incorporate protection of the natural and cultural resources as well as create income generating opportunities, educate local people, build capacity of local people and increase participation [6]. Tourism growth rate was total $28 \%$ in 2004 [7]. It incorporates conservation with involvement of local people in a sustainable way [8]. It focuses on commercial development, communal improvement, poverty mitigation, biodiversity and environmental protection [9]. Moreover, ecotourism plays a vital role in promoting recycling, energy efficiency and water conservation along with evaluating environmental and cultural factors [10]. Its role has been recognized as a catalyst for encouraging ecologically sustainable development with an amicable relationship with nature, local communities, their cultures and customs [11].

Ecotourism contribute greatly towards Gross Domestic Product (GDP) for developing countries like Nepal which are rich in natural environment and culture $[12,13]$. It raises sensitivity of the host country's political, environmental and social issues and supports international human rights and labor agreements [14]. Nepal is a geographically a small country however it has been blessed by tremendous diversity of flora and fauna. The country's 118 ecosystems harbor over $2 \%$ of the flowering plants, $3 \%$ of the pteridophytes and $6 \%$ of the bryophytes in the world's flora. Similarly, the country harbors $3.9 \%$ of the mammals, $8.9 \%$ of the birds and $3.7 \%$ of the world's fauna of butterflies [15]. 
Moreover, Nepal has been harboring over 100 species of medicinal herbs, 30 species of rhododendrons, 89 taxa of saxifraga, 77 taxa of prim land and over 350 species of orchidaceous species [16]. Nepal is an ideal country for promoting ecotourism with its natural beauty further amplified by lofty mountains, rich biodiversity and elegant landscapes. Ecotourism has gained popularity in Nepal and has played important role in national economy and environment conservation. However, it has also brought a series of negative impacts on environmental and cultural aspects. There is deforestation, pollution and cultural degradation in the protected areas due to tourism development activities [17]. The significant decline in the scenic beauty and greenery has been observed in the environment due to the construction of roads and other infrastructures disturbing the flow of tourist in the area. Local tradition and plain cultures has been intruded by the foreign cultures brought by tourists [18]. The enormous increase in number of tourist in the Sauraha leads to increased demand on resources like fuel and water and on the other hand causes impact on economic, environmental and socio-cultural aspects of the area [19]. Moreover, tourism has also demand for the construction of sophisticated infrastructure in and around Chitwan National Park which has indirect impacts on wildlife.

Ecotourism is the fastest expanding industry in Chitwan National Park which utilizes and conserves environmental resources. This research project will explore how ecotourism is being practiced in Chitwan National Park and also study positive and negative impacts of ecotourism on the local community. This research will also demonstrate perception of local people towards the positive-negative effects of ecotourism in terms of environment, socio-culture, and economics. Moreover, this study will also assist in generating awareness for the conservation and improvement of natural and cultural values and maintaining its sustainability.

\section{MATERIALS AND METHODS Study area}

Chitwan National Park was established in 1973 and is the first national park of Nepal [20]. It was listed in World Heritage Site in 1984. It covers an area of 932 $\mathrm{km}^{2}$ (360 sq. $\mathrm{m}$ ) and is located in the lowlands of southcentral Nepal in four districts i.e., Nawalparasi, Parsa, Chitwan and Makwanpur. Chitwan Nepal Park is rich in biodiversity and consists of more than 50 mammal species, over 525 birds, and 55 amphibians and reptiles [20]. Sauraha is the main entry point of Chitwan National Park and one of the most important tourism destinations in Nepal. It is 170 kilometers away from the capital city Kathmandu, $155 \mathrm{kms}$ from Pokhara, 160 $\mathrm{kms}$ from the Indian border at Sunauli and $23 \mathrm{kms}$ from Narayangarh city with geographic location $27^{\circ} 34^{\prime} 29^{\prime \prime} \mathrm{N}$ $84^{\circ} 29^{\prime} 37^{\prime \prime} \mathrm{E}$. It is popular among tourists for jeep safari, elephant safari, jungle walk, bird watching, elephant bath, Tharu culture, etc.

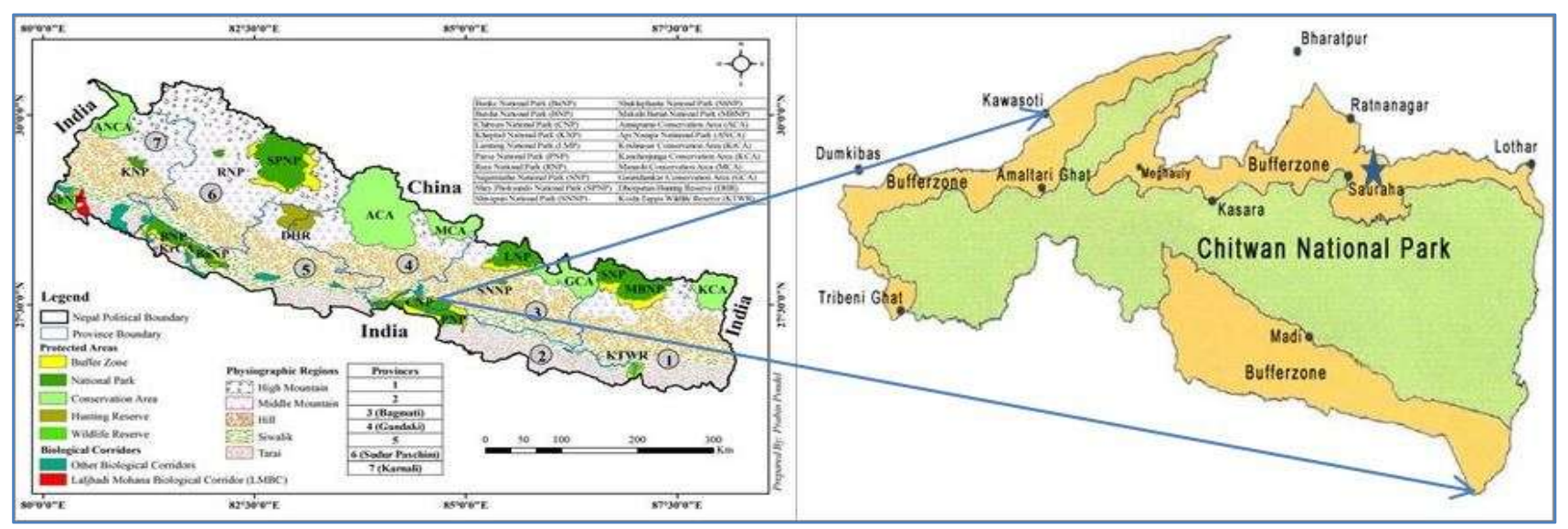

(Source: Kafle et al [36] \& Wikimedia and edited)

Fig-1: Protected area of Nepal and Study area Sauraha of Chitwan national Park

\section{DATA COLLECTION}

Reconnaissance survey was carried out for general understanding and collecting preliminary information of the ecotourism in the site. General Field observation was conducted to analyze impacts of ecotourism and rough format was prepared for each working. Key Informants Interviews with forestry staffs, local leaders, teachers, government employees etc. were carried out to obtain factual data about the study area and to verify the collected information. The different occupations carried out by local people and various impacts imposed were derived from the thorough visit of the study area. The information thus obtained was collected and recorded for further analysis. A semi-structured questionnaire was developed to collect information from local people. The interview was conducted with park staff, environmentalist, hotel owner, and women. Relevant and necessary data archival information was taken from various books, research articles, journals. Administrative and publicly available documents concerning ecotourism and articles, reports of 
Department of National Parks and Wildlife Conservation (DNPWC) and District Development Committee (DDC), Village Development Committee (VDC), National Park office (Kasara, Chitwan), IOF library, and municipality profiles were reviewed and taken as references.

\section{DATA ANALYSIS}

Both qualitative and quantitative data was collected. So, data was analyzed both qualitatively and quantitatively. Quantitative data was analyzed using descriptive statistics such as percentage, mean, frequency distribution and use of graphics. Whereas qualitative data was presented by illustrations; simple tables, charts, graphs and other pictorial forms. Data obtained from the field was fed into Ms-Excel and analyzed accordingly.

The perception and attitude of different level of respondents were measured in Likert Scale of (1-5) ranging from strongly agree to strongly disagree. The mean scores obtained on the Likert Scale were compared and used to determine the perception of respondents.

Other strong tests viz. Index of Perceived Availability (IPA) and Index of Relative Ranking were used to identify the people perception and the priority order of the expected activities. The formulas used in this regard were presented below: Index of perceived availability (IPA):

In the index of perceived availability (IPA), perceptions of local people towards eco-tourism activity can be calculated or analyzed by using following formula.

$\mathbf{I P A}=\mathrm{SD}(0.10)+\mathrm{D}(0.30)+\mathrm{N}(0.50)+\mathrm{A}(0.75)+\mathrm{SA}$ $(1.0) / \mathrm{n}$

Where, $\mathrm{N}=$ Number of responses

\section{Index of Relative Ranking (IRR)}

IRR can be used to determine the ranking value in the different heading of ecotourism. Miller [21] on his book stated that Index of Relative Ranking (IRR) can be calculated by using following formula.

$\mathbf{I R R}=\left(\mathrm{R}_{1} \mathrm{~S}_{1}+_{\mathrm{R} 2 \mathrm{~S} 2}+-------------+\mathrm{R}_{\mathrm{n}} \mathrm{S}_{\mathrm{n}}\right) / \mathrm{nr}$

Where, ${ }_{\mathrm{R} 1}=$ Rank of 1 st order

$\mathrm{S}_{1}=$ score of 1 st order

$\mathrm{R}_{\mathrm{n}}=$ Rank of last order

$\mathrm{Sn}=$ Score of last order

$\mathrm{n}=$ Number of observation

$\mathrm{r}=$ Total rank is given to particular attribute

\section{RESULT AND DISCUSSION}

Socio-economic condition of the respondent: The household survey was conducted in $10 \%$ of the total households. The given table provides information about socio-economic condition of the respondent.

Table-1: Socio-economic condition of the respondent

\begin{tabular}{|l|l|}
\hline Characteristics & Percentage \\
\hline Sex & \\
\hline Male & 37 \\
\hline Female & 63 \\
\hline Age group & \\
\hline Adult (>45 years) & 41 \\
\hline Middle age (26-45 years) & 54 \\
\hline Young (<25 years) & 5 \\
\hline Caste & \\
\hline Tharu & 48 \\
\hline Brahmin & 21 \\
\hline Tamang & 10 \\
\hline Chhetri & 5 \\
\hline Others & 16 \\
\hline Education & \\
\hline Illiterate & 10 \\
\hline Primary level & 46 \\
\hline Secondary level & 37 \\
\hline Higher Secondary & 7 \\
\hline Annual income & \\
\hline$<0.1$ million & 11 \\
\hline $0.1-0.2$ million & 53 \\
\hline $0.2-0.3$ million & 28 \\
\hline $0.3-0.4$ million & 8 \\
\hline & \\
\hline
\end{tabular}

\section{Status of tourism}

According to the annual report of DNPWC $2074 / 75$, the number of tourists visited CNP in fiscal year 065/66, 066/67, 067/68, 068/69, 069/70, 070/71, $071 / 72$, 072/73, 2073/74 and $2074 / 75$ was 118685 , $115181,146620,170112,153749,173425,178257$, 87391,139125 and 1186621 respectively. The status of tourism had declined in fiscal year $072 / 73$ because of the then-condition of the country i.e. unofficial blockades. (Fiscal year date: Nepali date)

\section{Purpose of visiting Sauraha}

According to our study among 81 households, $41 \%$ of the respondent considered that most of the tourist visited Sauraha for jungle safari, $17 \%$ for folk dance, $13 \%$ for bird watching, $5 \%$ for museum visit and $5 \%$ for research. This shows that majority of people visit Sauraha for jungle safari and least of them for museum visit and research. In other study conducted in Megahuli, majority of respondents i.e. $44 \%$ visited for Jungle Safari, $12 \%$ for viewing scenary, $10 \%$ for experiencing local village and culture and least only $4 \%$ for bird watching [22]. 
Local people's ranking on the existing eco-tourism related activities

IRR was used to calculate the relative position of the existing ecotourism activities. Local people were interviewed about the existing tourism activities in this area and asked to rank them accordingly, 5 being mostly done an activity by visitors. Their responses are as follows:

Table-2: Activities, Calculated IRR, Result and Ranking value

\begin{tabular}{|l|l|l|l|}
\hline Activity & Calculated IRR & Result & Ranking \\
\hline Jungle safari & 0.93 & Active & First \\
\hline Bird watching & 0.65 & Good & Third \\
\hline Museum visit & 0.44 & Fair & fourth \\
\hline Folk dance & 0.87 & Active & second \\
\hline Research & 0.21 & Fair & Fifth \\
\hline
\end{tabular}

\section{Impacts of ecotourism}

Economic impact: In the ranking used from 1 to 5, 1 refers to no benefit at all and 5 refer to extremely benefited state. Among the 81 respondents, none of them marked 1 which means everyone in the site was more or less benefited by ecotourism. Likewise, 5 respondents marked 2 and 11 of them marked 3. The highest number of the responses i.e. 48 has marked 4 while 17 of them reported that the local have been extremely benefited from ecotourism.

Out of 81 respondents, the majority $(65 \%)$ of them are involved in low-level employment with a monthly salary about Rs.8200-15000 among which 21 are male and 27 are female. While $25 \%$ of them are in medium level employment with a salary about Rs.15000-30000 among which 13 are male and 7 are female. And also, $10 \%$ of them are engaged in highlevel employment with a salary about Rs.30000-50000 among which 7 are male and 2 are female. This shows that status of female participation in tourism activities is still not satisfactory in comparison to male. (Current market exchange rate: $1 \$=R s 121$ ).
Participation in tourism related activities can increase employment opportunities and help local people to generate income for fulfilling their basic needs [23]. Similarly, tourism in Ghandruk has provided different source of income to the local villagers and assisted them to earn income and enhance their way of living [1]. Tourism may also provide opportunity to local people to sell their local products such as vegetables, fruits, livestock and others [24].

\section{Environmental impact}

After implementation of Annapurna Conservation Area Project (ACAP) in Ghandruk, forest areas and floral diversity got increased and helped to attract large number tourists [1]. In our study, out of 81 attendants, 59 of them agreed that tourism has increased pollution in Sauraha while 9 of them were neutral and 13 of them disagreed. This shows that majority (73\%) of respondent think tourism has led to increasing pollution in Sauraha. The pie chart below shows the response of people towards pollution in Sauraha. Similarly, study done by [25] showed that tourism can cause serious environmental problems like depletion of natural resources and environmental degradation.

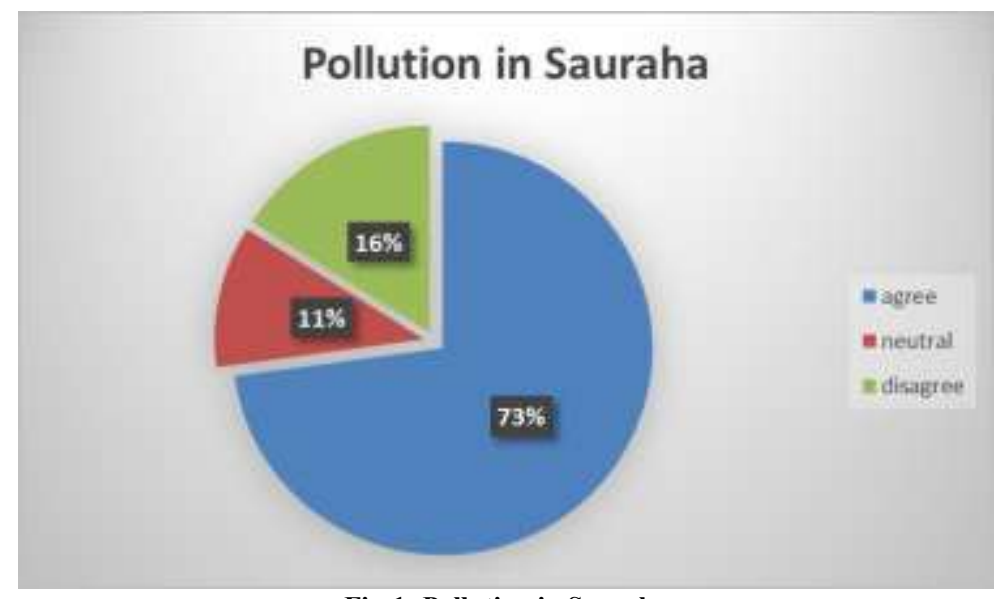

Fig-1: Pollution in Sauraha

The following bar diagram describes the type and level of pollution resulted as a result of tourism. As per the survey of 81 households, 35 of them (43\%) responded to crowdedness as the major environmental problem resulting in the noise pollution, whereas 25 of them $(31 \%)$ responded to air pollution as the major environmental problem. Likewise, 10 of them indicated towards land pollution and 12 of them selected others i.e. water pollution, loss of biodiversity etc. 


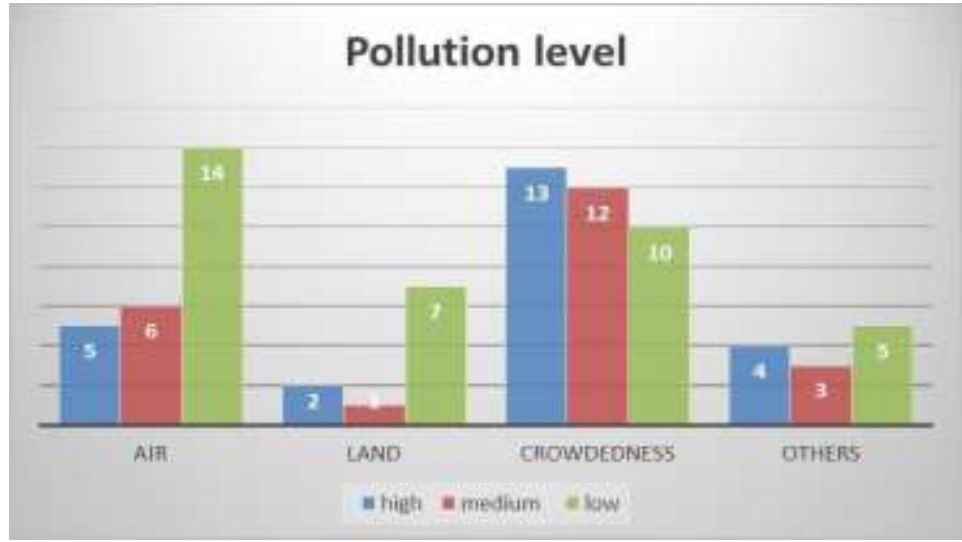

Fig-2: Pollution type and level

Socio-cultural impact: Out of total attendants, $48(59 \%)$ responded that tourism has positive impact, whereas $33(41 \%)$ of them responded that the tourism has a negative impact in the study area. To know whether the people are the socio-cultural impact of ecotourism, Chi-square test was done. The perception of the respondents in the following statement was rated on 5 point Likert scale. Two variables Gender (male and female) and Education (literate and Illiterate) were taken.

\section{Statement: Ecotourism causes undesirable commercialization of tradition and custom}

In case of gender, majority of male and female (26.58\%) strongly agreed on the statement. The overall mean response was 1.26. Similarly, in case of education category, $33.79 \%$ strongly agreed, $32.75 \%$ agreed, $49.31 \%$ neutral, $23.79 \%$ disagreed and $5.51 \%$ strongly disagreed on the statement.

Table-3: Ecotourism causes undesirable commercialization of tradition and custom

\begin{tabular}{|l|l|l|l|l|l|l|l|}
\hline Variables & Categories & \multicolumn{3}{l|}{ Response within category } & Mean Response \\
\hline & & Strongly Agree & Agree & Neutral & Disagree & $\begin{array}{l}\text { Strongly } \\
\text { Disagree }\end{array}$ & \\
\hline \multirow{2}{*}{ Gender } & Male & 0.49 & 0.25 & 0.27 & 0.33 & 0.22 & 1.56 \\
\cline { 2 - 8 } & Female & 0.18 & 0.29 & 0.15 & 025 & 0.1 & 0.97 \\
\hline \multirow{2}{*}{ Education } & Illiterate & 0.0 & 0.11 & 0.99 & 0.1 & 0.02 & 0.41 \\
\cline { 2 - 8 } & Literate & 0.49 & 0.84 & 0.44 & 0.59 & 0.14 & 2.5 \\
\hline Average & & & & & & & 1.45 \\
\hline
\end{tabular}

In Gabhar Valley, most of the age group (18$35)$ i.e. $64.6 \%$ believe that ecotourism can preserve culture and tradition of the area whereas, majority of age group above 50 disagreed on this statement this showed that old age people think ecotourism can bring negativity in the culture and tradition [26]. Other studies, in Western Sichuan Province showed that foreign culture of tourists caused impact on local tradition and culture in the area [18].

\section{List of income sources for local people}

Ecotourism activities have significantly contributed for the socio-economic upliftment of the local people. In the study area, different sources of income from ecotourism activities were recorded. Most of the women were involved in house-keeping /cleaning activities. Majority of the local people were involved in cooking, waiter, driver and house-keeping activities which play the vital role in economic contribution in households so that they could invest in their children's education. According to the response of the respondents from the questionnaire survey, the list of ecotourism related activities are as follows: Different business, Hotel, Restaurant, Service Business (Renting Cycle,
Binoculars), Employment (waiter, manager, housekeeping in hotels), Tourist Guide, Agricultural products, Fascinating traditional foods (Chicher, Ghugi etc.), Elephant, Cart-wheel riding etc.

Tourism activities like animal watching [27], bird watching, and home stay are also the major source of local people in the tourist destination.

According to study done by [28], restaurants, souvenir shops, guiding services, accommodation and entrance fees are the four major sources of revenue for the local people in the ecotourism destination. Moreover, farming activities along with tourism and many local businesses like handicrafts are other source of income [29].

\section{Range of income provided by hotel to the manpower}

The following table shows that hotel manager received highest income i.e. Rs. 30000-50000 per month, followed by cook i.e. Rs. 10000-30000 per month and least income is of house-keeping/cleaning i.e. Rs.500 per day. (1\$=RS 122). 
Table-4: List of income source

\begin{tabular}{|l|l|}
\hline Source of income & Salary per month (Rs.) \\
\hline Hotel manager & $30000-50000$ \\
\hline Cook & $10000-30000$ \\
\hline Waiter & $7500-15000$ \\
\hline Guide & $15000-25000$ \\
\hline Driver & $15000-20000$ \\
\hline House-keeping/ Cleaning & 500 per day \\
\hline Some shops & $20000-30000$ \\
\hline Others & - \\
\hline
\end{tabular}

\section{Women participation}

There are ranges of ecotourism-related activities in the study area. Out of all those activities, women participation is very low. According to the respondent of the survey, most of women are participated in low level employment i.e. minor shops, receptionist, waitress, house-keeping/cleaning, cook for hotel staff only etc. The given bar diagram presents women involvement more clearly. Other study done in Pokhara shows that most of the women involved tourism in Nepal are working in the lower positions as unskilled and semiskilled workers and get less benefits [30].

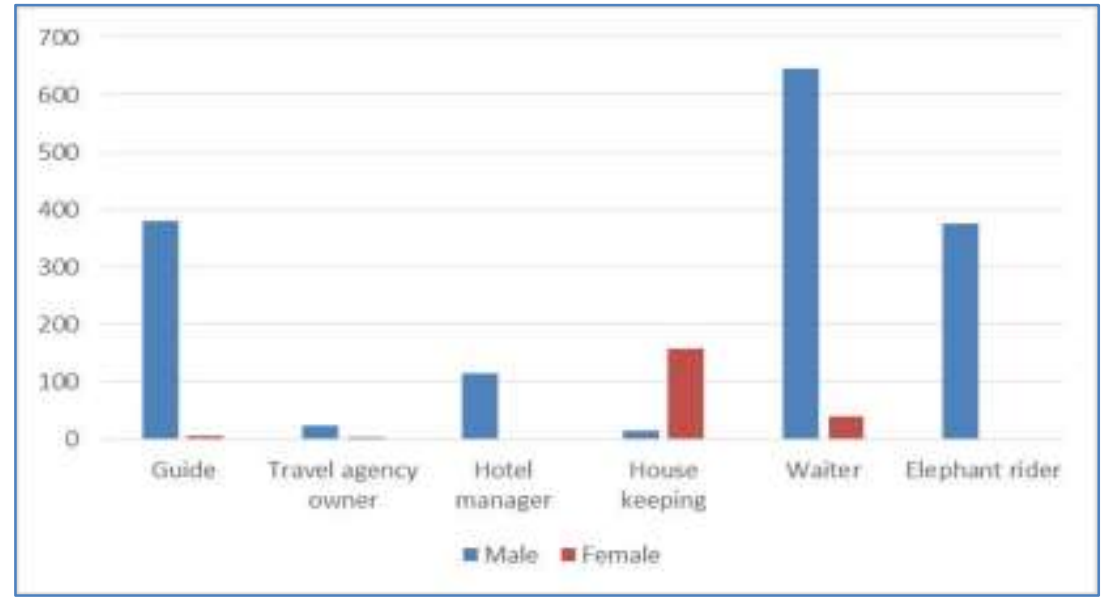

Fig-3: Women participation in Ecotourism related activities

\section{Index of Perceived Availability (IPA)}

Index of perceived Availability was used to check the people perception in which IPA value was compared to the highest (1) and lowest (0). During research periods, different statements were developed in order to check about their perceptions. In the following table, the highest IPA value (0.92) was received in the statement of new job opportunity or employment generation. People realized the ecotourism can generate the new employment generation. Likewise, IPA value is 0.8 on increasing in living standard of the people followed by IPA value $0.78,0.75,0.72,0.68,0.50$ and 0.49 respectively. The impact of ecotourism on disturbance to wildlife and natural environment is low (IPA 0.49). Overcrowding the tourist will negatively be impacts on wildlife and natural resource conservation.

Table-4

\begin{tabular}{|l|l|l|l|}
\hline S.N. & Statement & IPA Value & \multicolumn{1}{|c|}{ Perception } \\
\hline 1. & New employment Opportunity. & 0.92 & High (Remarkable) \\
\hline 2. & Inflation. & 0.75 & High \\
\hline 3. & Rise in living standard. & 0.8 & High (Remarkable) \\
\hline 4. & Change in habits. & 0.7 & High \\
\hline 5. & Festival etc. activities rise. & 0.67 & High \\
\hline 6. & Increase women participation in different income earning. & 0.74 & High \\
\hline 7. & Inward emigration. & 0.78 & High (Remarkable) \\
\hline 8. & The emergence of noise and visual pollution. & 0.46 & Low \\
\hline 9. & Hotel, motel or other usages cause environmental changes. & 0.59 & Medium \\
\hline 10. & Disturbance to wildlife and natural environment. & 0.49 & Low \\
\hline 11. & The scarcity of agricultural land. & 0.72 & High \\
\hline 12. & Conservation of local culture. & 0.5 & Medium \\
\hline
\end{tabular}




\section{Issues and Challenges}

Quick change in climatic condition [31, 32, 33], Global Pandemic like COVID-19 [34, 35] make fear to the tourists. Unhealthy competition of hotels and restaurants, low quality restaurants, load shedding problems, not a proper visitor center, limited skilled tourist guide etc. are major issues for ecotourism promotion in the area.

\section{CONCLUSIONS}

From the study it can be concluded that arrival of tourist to this area has created new job opportunities, increased women participation in eco-tourism related activities and conservation of local culture. It has also lead to over-crowdedness, emergence of visual pollution and inflation. Jungle safari was the highest ranked tourism activity which is done in Sauraha. After jungle safari, bird watching, museum visit, folk dance and research lie respectively. Lifestyle of local community has drastically changed due to high inflow of tourists. Thus, Ecotourism has caused environmental, social and economic impacts to the area.

\section{REFERENCES}

1. KC A, Rijal K, Sapkota RP. Role of ecotourism in environmental conservation and socioeconomic development in Annapurna conservation area, Nepal. International Journal of Sustainable Development \& World Ecology. 2015 May 4;22(3):251-8.

2. KC A, Thapa Parajuli RB. Climate change and its impact on tourism in the Manaslu conservation area, Nepal. Tourism Planning \& Development. 2015 Apr 3;12(2):225-37.

3. Sukhdev P, Stone S, Nuttall N. Green economy, developing countries success stories. St-MartinBellevue: United Nation Environment Programme (UNEP). 2010.

4. Anup KC. Ecotourism in Nepal. The Gaze: Journal of Tourism and Hospitality; 2017.

5. TIES. 2015. Retrieved on January 28, 2019 from the World Wide Web: http://www.ecotourism.org

6. Ross S, Wall G. Evaluating ecotourism: the case of North Sulawesi, Indonesia. Tourism management. 1999 Dec 1;20(6):673-82.

7. Baral N, Stern MJ, Bhattarai R. Contingent valuation of ecotourism in Annapurna conservation area, Nepal: Implications for sustainable park finance and local development. Ecological Economics. 2008 Jun 15;66(2-3):218-27.

8. Dowling RK. Global ecotourism at the start of the new millennium. World Leisure Journal. 2000 Jan 1;42(2):11-9.

9. Duffy R. Neoliberalising nature: Global networks and ecotourism development in Madagasgar. Journal of Sustainable Tourism. 2008 Jun 23;16(3):327-44.

10. Arrow RJ, Cline WR, Maller KG, Randall A. Resource economics.
11. Sindiga I. Alternative tourism and sustainable development in Kenya. Journal of sustainable tourism. 1999 Apr 1;7(2):108-27.

12. Amati C. "We all voted for it": experiences of participation in community-based ecotourism from the foothills of Mt Kilimanjaro. Journal of Eastern African Studies. 2013 Nov 1;7(4):650-70.

13. UNEP. Tourism: Trends, Challenges and Opportunities Green Economy and Trade United Nations Environment Programme. 2013; 259-291.

14. TIES. 1990. What is Ecotourism. Retrieved May 14, 2019, from https://www.ecotourism.org/whatis-ecotourism

15. Paudel PK, Bhattarai BP, Kindlmann P. An overview of the biodiversity in Nepal. InHimalayan biodiversity in the changing world 2012 (pp. 1-40). Springer, Dordrecht.

16. Chaudhary RP. Ecotourism: Bridge between biodiversity conservation and development in Nepal. Inproceedings of the International Symposium on the Himalayan Environments: Mountain sciences and Ecotourism/Biodiversity. Hokkaido University Japan 2001.

17. Musa G, Hall CM, Higham JE. Tourism sustainability and health impacts in high altitude adventure, cultural and ecotourism destinations: A case study of Nepal's Sagarmatha National Park. Journal of Sustainable Tourism. 2004 Jul 1;12(4):306-31.

18. Bin L, Suocheng D, Mei X. Ecotourism Model and Benefits of Periphery Regions in Western Sichuan Province. Chinese Journal of Population Resources and Environment. 2008 Jan 1;6(2):80-6.

19. Gurung P. Ecotourism as feasible development model, minimum impacts, maximum experience: Case Sauraha and Chitwan National Park.

20. Bhusal NP. Chitwan National Park: a prime destination of eco-tourism in Central Tarai Region, Nepal. The Third Pole: Journal of Geography Education. 2007:70-5.

21. Miller AD, Buttimore CA. Redesign of retrovirus packaging cell lines to avoid recombination leading to helper virus production. Molecular and Cellular Biology. 1986 Aug 1;6(8):2895-902.

22. Subedi BR. Prospective and challenges: Tourism development at Meghauli. Journal of Advanced Academic Research. 2014;1(2):74-84.

23. Stem CJ, Lassoie JP, Lee DR, Deshler DJ. How'eco'is ecotourism? A comparative case study of ecotourism in Costa Rica. Journal of sustainable tourism. 2003 Oct 1;11(4):322-47.

24. Budhathoki B. Impact of homestay tourism on livelihood: a case study of Ghale Guan, Lamjung, Nepal (Master's thesis, Norwegian University of Life Sciences, Ås).

25. Neto F. Sustainable Tourism, Environmental Protection and Natural Resource Management: Paradise on Earth?. Growth. 1990; 1999:2000.

26. Karki S, Baral K, Gautam D, Jandug CM, Khanal L, GC DB. Assessing the Opportunities of 
Promoting Ecotourism in Gabhar Valley: A case study from Buffer Zone of Banke National Park. Asian Journal of Arts, Humanities and Social Studies. 2019:57-66.

27. Dahal D, Gautam D, Bhattarai S, Khanal L, Baral K, Acharya KR. Potentiality of Pangolin based Ecotourism in Chuchhekhola Community Forest, Makawanpur, Nepal. 2019.

28. Lacher RG, Nepal SK. From leakages to linkages: Local-level strategies for capturing tourism revenue in Northern Thailand. Tourism Geographies. 2010 Jan 21; 12(1):77-99.

29. Singh TV, Singh S. On bringing people and park together through ecotourism: The Nanda Devi National Park, India. Asia Pacific Journal of Tourism Research. 2004 Mar 1; 9(1):43-55.

30. Palikhe A, Women Empowerment in Tourism: Special Reference to Pokhara Metropolitan City. Journal of Nepalese Business Studies. 2018. 11(1), 35-44.

31. Sharma G, Gautam D, Jandug CM, Bhattarai S, GC D, Baral K, Manandhar B, Sidgel R. Climate Change Impact and Local Adaptation Strategies at Chitlang, Makwanpur, Nepal. 2019. DOI: 10.36346/sarjhss.2019.v01i04.013
32. Gautam D, Bhattarai S, Sigdel R, Jandng C. MB., Mujahid, A. and GC, DB. Climate variability and wetland Resource in Rupa Lake Catchment, Nepal; 2019. DOI: $\underline{10.5281 / \text { zenodo. } 3568477}$

33. Bhattarai B, Sigdel R, Gautam D, Jandug CM, Sharma J. People's Perception on Climate Change, its Impact and Adaptive Strategies in Kaligandaki Rural Municipality, Syangja, Nepal. 2020. DOI: $10.36346 /$ sarjbab.2020.v02i01.001

34. Dhami B, Bista S, Sadadev BM, Chhetri HB, Poudel A, Lamichhane A, Poudel A, Gautam D. Overview of Novel Corona virus (COVID-19) and its linkage to economy of Nepal.2020. DOI: $\underline{10.5281 / \text { zenodo. } 3836903}$

35. Timilsina B, Adhikari N, Kafle S, Paudel S, Poudel S, Gautam D. Addressing Impact of COVID-19 Post Pandemic on Farming and Agricultural Deeds.2020. DOI: $10.9734 / A J A R R / 2020 / v 11 i 430272$

36. Kafle K, Thanet DR, Poudel P, Gautam D, Thapa G, Bhatt P. Status and conservation threats to large mammals of the Laljhadi Mohana Biological Corridor, Nepal. Journal of Animal Diversity. 2020 Jun 10; 2(2):0-0. 